IBT Journal of Business Studies

Volume 14(2), 27-40, 2018

\title{
The Linkage among Customer Equity Drivers: Building Customer Value Equity Model
}

\author{
Ammar Ali Khan \\ Wisal Ahmad' \\ Faisal Aftab
}

\begin{abstract}
This study examines the relationship among customer equity drivers and develops the customer value equity model. Many companies are facing the problem of how to use the customer equity and which of its drivers should be focused first. By exploiting the relationship among customer equity drivers, a customer value equity model is developed and tested in the fast food sector. Data was collected from three hundred consumers of national and multinational fast food restaurants in Peshawar. The findings of the study revealed that there is a significant relationship among the customer equity drivers such that brand equity of a fast food restaurant is significantly related with customer value equity as well as customer relationship equity. Similarly, customer relationship equity is significantly related with customer value equity. Hence, the study empirically validates the model of customer equity drivers which provides a sound base at least in its initial stage for marketing managers to develop and manage the value equity of their brand. The study findings present important theoretical and practical implications along with future research directions.
\end{abstract}

Keywords: Customer Brand Equity, Customer Relationship Equity, Customer Value Equity.

1- MBA Scholar, Institute of Business Studies, KUST, ammaralikhan@gmail.com

2- Assistant Professor, Institute of Business Studies, KUST, wisal ahmad@hotmail.com

3- Professor, Department of Management Science, BAHRIAUniversity Islamabad: faisal.aftab@gmail.com 


\section{INTRODUCTION}

In deciding the value of a company, it is important to know the customer base of a company which would ensure future revenues. The greater the customer equity (CE), the more future revenue in the lifetime of its clients; implying that a company with a higher customer equity can get more money from its customers on average than another company that is identical in all other characteristics. As a result, a company with higher customer equity is more valuable than one without it. It includes customers' goodwill and extrapolates it over the lifetime of the customers. There are three drivers to customer equity, all of which refer to three sides of the same thing namely brand equity, relationship equity and value equity (Keller, 1998). Brand equity is what the customer assesses the value of the brand (Aaker, 1991). Relationship equity is the tendency of the customer to stick with the brand even when it is priced higher than an otherwise equal product. Similarly, the customer value equity is what the customer assesses the value of the product or service provided by the company to be (Kumar \& George, 2007).

The consequences of greater positive customer equity have been much studied suggesting that it has significant positive implications for the respective businesses. Further, different topologies have been used by different researchers for conceptualizing or measuring the effects of customer equity such that some researchers have looked into it from customer knowledge based view and others have defined it as relationship or value equity. While critically reviewing the customer equity literature, this study believes that different topologies of customer equities lead towards the same outcome. More simply, whether it is the customer based brand equity model of Keller (1998), the five components model of Aaker (1991) which includes brand awareness, brand loyalty, perceived quality, and brand associations or relationship equity and value equity. Relationship equity covers customer equity from the perspective of customer and brand relationship whereas value equity covers the customer's objective assessment of the utility of a brand based on his or her perception of benefits compared to the cost paid for the brand. This study believes that outcomes of these three drivers or equities are same such that the eventual outcome of relationship equity in the customer equity topology results into consumer bonding with the brand. Similarly, consumer loyalty is the ultimate outcome of consumer brand equity in the customer equity topology. Hence, if any of this equity positively enhances, it will ultimately improves customers' bonding with the brand. Further, since customers with greater relationship equity and brand equity have greater customer bonding and loyalty with the brand, therefore, such customers would have greater positive perceptions about the value of the brand. In other words, greater positive relationship equity and brand equity will lead towards greater positive value equity. Previously these equity components have been considered as the three antecedents of customer equity (Aaker \& Jacobson, 2001). Based on the discussion, this study however proposes and tests that the relationship equity and brand equity, the two components of customer equity drives the third driver of customer equity, that is, customers' value equity. Unlike previous studies on the consequences of customer equity for companies, this study is the first of its nature to propose a new model of customer value equity by looking into the linkage of the customer equity drivers such that brand equity and relationship equity builds customer value equity.

\section{LITERATURE REVIEW}

\section{Customer Equity}

Business environment is highly competitive and to stay in this environment, firms need loyal customers and to make the customer loyal, firms need to understand the customer equity. Customer equity is born due to the growth in customer-centered market situations like micro segmentation of customer groups, higher customer expectations, hyper-competition, and digital technology revolution (Rust, Lemon \& Zeithmal, 2001). According to Rust et al (2001), customer equity is the sum of the discounted lifetime's values of all the firm's customers. 
Many mangers nowadays think and believe that growing the lifetime value of their customer relationships should be the priority of the company (Rust et al., 2001). By using the customer specific marketing action companies can manage to sustain the firm-customer relations for long time and by looking at customers as the assets (Kumar \& George, 2007). The customer equity is the tool by which a firm can measure the expected future behavior of the firm's customer. Customer equity can give the firm competitive edge and can maximize the long-term performance of the firm (Vogel, Evanschitzky \& Ramaseshan, 2008).

From the past, the famous firms are focusing their marketing activities on customers than on product line. The product oriented concepts are being replaced by the customer focused concept of customer equity (Hogan, Lemon \& Rust, 2002). The customer equity is formed from the different researches of the marketing like direct marketing, service quality, relationship marketing and brand equity. However, alone none of these marketing researches are not able to give the complete solution to the challenges facing by the firms today (Hogan, Lemon \& Rust, 2002).

Blattberg and Deighton (1996) were the first who introduced customer equity term first and defined it as the total discounted lifetime values of the company's current and prospective customer (Hogan, Lemon \& Rust, 2002). The Blattberg and Deighton (1996) model described the importance of a company's customer and by using this model companies can estimate that how much investment is required for the customer acquisition and retention (Hogan, Lemon \& Rust, 2002).

Customer equity is the straightforward activity. The customer gives the financial benefit to the company; to keep, sustain and grow should be the aim of the organizations like any other asset of the company (Blattberg, Getz \& Thomas, 2001). From this we can assume that the only purpose of the investment on marketing activities is to increase firm's customer equity and if the investment on the marketing activities is unable to improve customer equity is only the reason that the investment is wrongly spent (Rust, Lemon \& Zeithml, 2006).

\section{Brand Equity}

According to the Rust, Zeithaml and Lemon (2001), brand equity is the customer's subjective and intangible judgment of the brand, above and beyond its perceived value as an objective. Brand equity is more subjective, emotional and experiential appraisal of a brand than value equity (Keller, 1998) and is produced by images and own personal meanings. Aaker (2002) states that brand equity tell what is in the customer's heart and soul. According to Baldauf, Cravens and Binder (2003), brand equity positively and significantly influence customer value perceptions due to which customer purchase increases and firm profitability also increases.

Brand equity provides three important roles. First of all, its attract the new customers towards the firm product and services like a magnet. Second, it helps the customer to remind the product and services of the firm while they doing shopping. Finally, it creates the emotional attachment of product and services of the firm with the customer (Rust \& Verhoef, 2005). Hence, we say that brand equity is the set of assets that are linked to brand name that can add or subtract something from the brand value (Aaker, 1993). Although, most often companies forget that brands exist in the mind and heart of the customer, not exists on the packaging that only consist brand name and logo. In other words, a company may own a brand names and logo, its customers "own" the brand. These brands that live in customers' mind are created and recreated by the customer by watching the different brand advertising messages (Duncan \& Moriarty, 1997). Besides, Rust and Verhoef(2005) emphasize that brand equity represents the customer's subjective and intangible assessment of the brand above and beyond its objectively perceived value. 


\section{Relationship Equity}

Relationship equity is like the glue between customer and brand which force the customer to buy the same brand again and again, above and beyond the customer's objective and subjective judgment of the brand, comes due to relationship management (Rust \& Verhoef, 2005). We can also say that relationship equity is like a tool which is used to create and sustain the relationship between customer and organization (Zeithaml, Bitner \& Gremler, 2006). If the customer feels well treated its mean the relationship equity is high (Kristof, Odekerken-Schröder \& Iacobucci, 2001).

Rust, Zeithaml and Lemon (2000) write in their book that relationship equity first create the strong relationship between customer and firm that customer will continue the purchasing in future with the firm and secondly make the increase in future purchases of the customer and at last reduce the chances that the customer will purchase from the competitor. Furthermore, Vogel, Evanschitzky and Ramaseshan (2008) suggest that relationship equity is one of the very important driver of future sales and firm must use this driver to sustain customer by establishing strong relation with the customer. Drivers of relationship equity are given by Rust et al. (2000).

\section{Value Equity}

According to Rust, Lemon and Zeithaml (2001), value equity describes the customer's objective judgement of the use of a brand, based on that how he or her perceived the benefits to costs. We can also say that customer analysis the amount of money they give for the benefit they receive from the brands (Rust et al., 2001; Zeithaml, 1988).

Value equity is the side stone of the customers' relationship with the firm. If the company's products and services is unable to fulfill the customer's needs and expectations, then even a best brand strategy and even strongest retention and relationship marketing strategies will not do anything for the brand success (Rust \& Verhoef, 2005). According to Vogel, Evanschitzky and Ramaseshan (2008), value equity is the most important driver of customer equity in increasing future sales and tells the firm that firms should meet customers' expectations. As indicated by Rust et al. (2000), value equity consists of three drivers, namely quality, price and convenience.

Linkage between Customer Brand Equity and Customer Value Equity:

Raggio and Leone (2007) agree with the idea that customer brand equity and customer value equity both are different construct, but have a different way of looking issue. According to them, customer brand equity moderates the impact of marketing activities on consumer actions and represents one of many factors (i.e. Brand awareness, Perceived quality, Brand associations and Brand loyalty) that create the customer value equity, which the authors define as value of a brand sale or a replacement.

Customer value equity is used to measure the value of the brand of the company and value of the company itself. However, it is important to understand how customer brand equity is created and sustained in the minds of consumers and how this translates into purchase behavior and consumption (Crescitelli \& Figueiredo, 2009). In other word, it is impossible to have customer value equity without having customer brand equity first. Hence we can say that customer brand equity is the driver of customer value equity.

Aaker and Jacobson $(1994 ; 2001)$ showed the relationship between measures of consumer perceptions about the brand and the brand's financial performance. World famous brand valuation companies like Inter-brand and Brand Finance, use financial performance as the indicators in the financial market to measure the financial value of brands, to find the ranking of the brand that which brands are the most valuable brands. These firms use both brand equity and the point of view of consumers as performance measures to calculate brand value. 
Customers have stronger and more favorable associations with brand, and feel higher familiarity with the brand due to customer brand equity (Keller, 2003; Slotegraaf \& Pauwels, 2006). It would seem that customer brand equity increases the customer value equity of products (Mizik \& Jacobson, 2009). Customer brand equity facilitate information processing and interpretation of customer, create trust for consumers in making purchases, and provide consumers with the satisfaction of use (Aaker, 1996b; Aaker, 1998). Customer brand equity are seen as adding value, to the extent that they also socially qualify the buyer (Kapferer, 2004). The above shows that customer brand equity can bring value to the customer.

Customer brand equity and customer value equity can both bring value to the company. Customer brand equity is very valuable for the company because it helps to improve the marketing programs efficiently and effectively (Aaker, 1991; Crawford \& Benedetto, 2006). Customer brand equity helps the company's communications programs, due to which customers able to accept the company's communications programs (Aaker, 1996b), and makes advertising and other methods of promotion more efficient and effective (Mizik \& Jacobson, 2009). Customer brand equity increases consumer preference towards the brand and purchase intention (Aaker, 1998; Cobb-Walgren, Ruble \& Donthu, 1995), brand loyalty (Mizik \& Jacobson, 2009; Kapferer, 2004), and demand from customers (Agarwal \& Rao, 1996). It also helps to increase market share (Christodoulides \& Chernatony, 2009; Raggio \& Leone, 2007) and is an instrument for leveraging sales and profitability (Slotegraaf \& Pauwels, 2006; Aaker, 1996b; Aaker, 1998). It provides a sustainable competitive advantage for organizations, that is, an advantage that can be maintained over time and which can be difficult to imitate by competitors (Crawford \& Benedetto, 2006). Therefore, a company that has customer brand equity will be less vulnerable to the marketing activities of competitors (Aaker, 1996b; Keller, 1998; Bendixen, Bukasa \& Abratt, 2003; Wood, 2000). In all, we conclude that brand equity brings the customer value equity to a company.

The author can also say that; it is impossible to create customer value equity without creating customer brand equity first. Hence, we can assume that customer brand equity is the driver of customer value equity.

More simply, it implies that consumers first develop associations with the brand and associate it with certain functional as well as imagery benefits that determine the actual consumption behavior of the consumer. Since value equity is the customers' perception of the benefits associated with the brand, it can be implied that customer brand equity determines the value of the brand in consumers' mind. Hence, it can be proposed that:

\section{H1: Customers brand equity has a significant positive effect on customer value equity for the respective brand. \\ Linkage between Customer Relationship Equity and Customer Value Equity}

Findings of many studies is all about measuring the CRM's effects on end results, i.e. on profit and shareholder value, without understanding and studying those factors which antecedents of relationship equity variables (Boulding, William, Staelin, Ehret \& Johnston, 2005). Although the specifics will be unique to each firm, prior research provides a conceptual framework for understanding how relational processes create value for customers. Specifically, research on the antecedents of service quality, customer satisfaction, trust, and commitment provide insights for managers (Berger, Paul, Ruth, Bowman, Briggs, Kumar Parasuraman \&. Terry, 2002).

Customer relationship equity and customer value equity both are related with each other. Different terms have been used for relationship equity or to describe similar concepts (Buttle, 1996). These include direct marketing, database marketing, customer relationship marketing, data driven marketing, micro marketing, one to one marketing, loyalty based marketing, segment of one 
marketing, customer partnering, dialogue marketing and interactive marketing. All this suggests that customer relationship equity is also an umbrella philosophy for rational approaches in marketing. Customer relationship equity is used to provide the increased value to the customer and results in a lifetime value for the service provider (Liu, Sudharshan \& Hamer, 2000).

Customer relationship equity is the reason of effective communication and quality as important factors in relationship development, maintenance and performance and customer value equity (Anderson \& Narus, 1984; Anderson \& Narus, 1990; Berry \& Leonard, 1995). Key dimensions of communication quality appear to include timeliness, frequency, openness and accuracy. Communication enhances the customer relationship equity, build the trust, commitment and eventually increase the customer value equity (Selnes, 1998; Lewin \& Johnston, 1997).

By using customer relationship equity companies can create one to one relationship with the customers (Pppers \& Rogers, 1993) and then companies can create added value (Nykamp, 2001; Payne \& Frow, 2005), control cost and spending (Johnsons \& Nunes, 2003) and analyze customer value (Nykamp, 2001). Payne and Frow (2005) found that with the help of customer relationship equity companies can examine the value creation process and found that business and customer strategy evaluations can be transformed into implementable programs, which create value for both the customer and the organization.

From the above literature we can say that CRM not only create the customer relationship equity but also create the customer value equity because creating bonding i.e. strong relation is not only the ultimate goal but maintaining and sustaining this relation for life time is the ultimate goal and for this CRM needs to create the value for the customer which is the customer value equity.

Hence, it can be proposed that:

\section{H2: Customer relationship equity has a significant positive effect on customer value equity for the respective brand. \\ Linkage between Customer Brand Equity and Customer Relationship Equity:}

Many studies have indicated that brand equity is logically a precursor of customer relationship equity which is again emphasis the linkage between brand equity and customer relationship equity (Stahl \& Heitmann, 2012). If brand wins the hearts and minds of customers than it is easier to retains/acquires customers. This perspective is supported by the hierarchy of effects model of customer behavior such as AIDA model which posit that customer attitudes are a precursor to consumer actions (Lavidge \& Steiner, 1961). Research support the notion that brand equity should link to measure of customer relationship equity such as a conceptual model linking brand equity and customer relationship equity (Leone, Rao \& Keller, 2006) and using statistical approach analyzes the impact of brand equity to customer acquisition and retention (Stahl \& Heitmann, 2012).

Brand equity drives the relationship equity and plays an important role in management of relations with customers in long terms. Also it is used as a tool to enhance the satisfaction and service quality (Taylor, Celuch \& Goodwin, 2004). Due to tough competition in the marketing world, making new customers is very expensive and offering different services is also too expensive that's why retaining existing customers is very important. For this purpose, a strong relation with the customers is very important and to make that strong relation with the customer brand equity is the right tool. Relationship equity due to brand equity will finally lead to customer satisfaction and loyalty (Javadinet et al., 2010).

Today, companies having strong brand equity has the competitive advantage. Brand equity brings material and spiritual benefits for the company (Akhlaq et al., 2010). Brand equity is very important area in the marketing management, especially when organizations change their efforts to 
communicate the intangible and complex messages (Goodchild \& Callow, 2001). One of the most important issues facing today's brand managers is how to provide a better understanding about those factors such as the relationship between brand and customer loyalty, especially considering the fact that the marketing management literature suggests many factors which affect customer loyalty (Mittal $\&$ Kamakura, 2001). Brand and Trademark are the main issues raised in enterprise product mix strategy. Businesses make large and long-term investment for their brand, especially in the fields of advertising, sales promotion and packaging. They know that the power of the market is generated from the brand equity and strong brand equity brings customer loyalty. Perhaps the most distinctive skill of professional firms is their ability to create, preserve and develop their brands (Capferer, 2006). Research shows that the cost of maintaining customer loyalty is less than the cost of attracting a new customer (Javanmard \& Soltanzadeh, 2009). Therefore, in order to expand and grow the business in the market companies need to understand the role of relationship equity, which is the precursor of the brand equity to stay in the completion and to get the competitive edge over other competitors and to make the customers loyal to the company (Javadin et al., 2010).

So we can say that there is some relation between customer relationship equity and customer brand equity because without customer relationship equity brand cannot sustain the customer for long time and without customer brand equity customer cannot become the loyal customer.

Hence, it can be proposed that:

\section{H3: Customer brand equity has a significant positive effect on customer relationship equity.}

\section{THEORETICAL FRAME WORK OF THE STUDY}

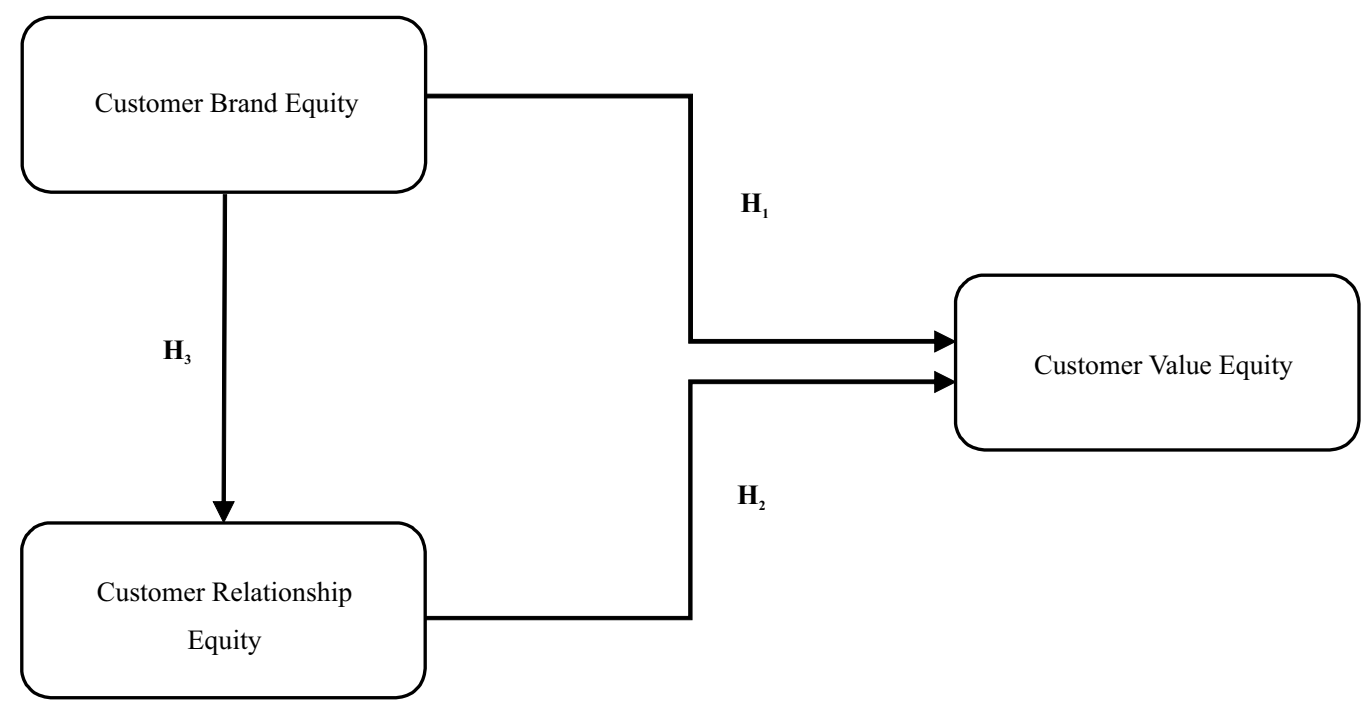

\section{METHODOLOGY}

The aim of this research is to develop a preliminary model of customer value equity by looking into the linkage of customer equity drivers. In order to test the applicability of the proposed model, the population of the study is consisting of brand sensitive customers in Fast Food sectors of different multinational fast food chains. Since the population of the study, that is, all fast food consumers is unknown, a randomized list of research respondents cannot be generated. Hence, a convenience sampling technique is used. In the light of sample selection principles stated by Sekaran (2003), a targeted sample size of 300 responses was deemed sufficient for this study. Keeping in view sample sizes in previous studies were 146 and 190 responses (Kazemi, Abadi \& Kabiry, 2013; Wu \& 
Batmunkh, 2010) and data is collected from fast food customers in the various fast food points of KFC, Chief Burger, and other fast food stores in Peshawar. The study variables are measured on 5 point Likert scale through a validated instrument where $1=$ strongly disagree and $5=$ strongly agree. Since, the research study is about validating a relationship model of Customer value equity, the relationships between the collected data is analyzed for the simultaneous relationship through regression analysis.

\section{RESULTS}

The first hypothesis of the study is,

\section{H1: Customers brand equity has a significant positive effect on customer value equity for the respective brand.}

In order to test the relationship between customer brand equity and customer value equity, regression analysis was performed. The descriptive statistics stated that both the customer brand equity and customer value equity seems closely related. The regression analysis as in model summary and ANOVA reveal that the model between the two factors (customer brand equity and customer value equity) is significant. Further, the beta coefficient value of customer brand equity reveals that customer brand equity has fifty-seven explanatory roles in influencing customer value equity. Hence, hypothesis $\mathrm{H} 1$ is therefore supported.

\begin{tabular}{|c|c|c|c|}
\hline \multicolumn{4}{|c|}{ Table 2: Descriptive Statistics } \\
\hline & Mean & Std. Deviation & $\mathrm{N}$ \\
\hline Mean Customer Value Equity & 3.5425 & .81355 & 300 \\
\hline Mean Customer Brand Equity & 3.5795 & .66771 & 300 \\
\hline
\end{tabular}

\begin{tabular}{|c|c|c|c|c|c|c|c|c|c|}
\hline \multicolumn{10}{|c|}{ Table 3: Model Summary } \\
\hline \multirow[b]{2}{*}{$\begin{array}{c}\text { Mod } \\
\text { el }\end{array}$} & \multirow[b]{2}{*}{$\mathrm{R}$} & \multirow[b]{2}{*}{$\begin{array}{c}\mathrm{R} \\
\text { Square }\end{array}$} & \multirow[b]{2}{*}{$\begin{array}{l}\text { Adjusted } \\
\text { R Square }\end{array}$} & \multirow[b]{2}{*}{$\begin{array}{l}\text { Std. Error } \\
\text { of the } \\
\text { Estimate }\end{array}$} & \multicolumn{5}{|c|}{ Change Statistics } \\
\hline & & & & & $\begin{array}{l}\mathrm{R} \text { Square } \\
\text { Change }\end{array}$ & $\begin{array}{l}\text { F } \\
\text { Chang } \\
\text { e }\end{array}$ & df1 & $\mathrm{df} 2$ & $\begin{array}{l}\text { Sig. F } \\
\text { Change }\end{array}$ \\
\hline 1 & $.569^{\mathrm{a}}$ & .324 & .322 & .66986 & .324 & $\begin{array}{l}143.03 \\
2\end{array}$ & 1 & 298 & .000 \\
\hline \multicolumn{10}{|c|}{ a. Predictors: (Constant), Mean Customer Brand Equity } \\
\hline
\end{tabular}

\begin{tabular}{|l|l|l|l|l|l|l|}
\hline \multicolumn{9}{|c|}{ Table 4: ANOVA } & Sig. \\
\hline \multirow{2}{*}{ Model } & Sum of Squares & Df & Mean Square & F & $.000^{\text {b }}$ \\
\hline \multirow{3}{*}{1} & Regression & 64.180 & 1 & 64.180 & 143.032 & \\
\cline { 2 - 6 } & Residual & 133.716 & 298 & .449 & & \\
\cline { 2 - 7 } & Total & 197.896 & 299 & & & \\
\hline \multicolumn{2}{|l|}{ a. Dependent Variable: Mean Customer Value Equity } & & \\
\hline
\end{tabular}

\section{H2: Customer relationship equity has a significant positive effect on customer value equity for the respective brand.}

Regarding H2, the customer relationship equity was regressed with customer value equity. Results show in descriptive statistics that the relationship between customer relationship equity and customer value equity seems closely related. The regression analysis as in model summary and ANOVA reveal that the model between the two factors (customer relationship equity and customer value equity) is significant. Further, the beta coefficient value of customer relationship equity reveals that customer relationship equity has sixty-three explanatory roles in influencing customer value equity. Hence, hypothesis $\mathrm{H} 2$ is therefore supported. 


\begin{tabular}{|c|c|c|c|c|c|c|}
\hline \multicolumn{7}{|c|}{ Table 5: Coefficients ${ }^{\mathrm{a}}$} \\
\hline & \multirow[t]{2}{*}{ Model } & \multicolumn{2}{|c|}{ Unstandardized Coefficients } & $\begin{array}{l}\text { Standardized } \\
\text { Coefficients }\end{array}$ & \multirow[t]{2}{*}{$\mathrm{t}$} & \multirow[t]{2}{*}{ Sig. } \\
\hline & & $\mathrm{B}$ & Std. Error & Beta & & \\
\hline \multirow[b]{2}{*}{1} & (Constant) & 1.059 & .211 & & 5.012 & .000 \\
\hline & $\begin{array}{c}\text { Mean Customer Brand } \\
\text { Equity }\end{array}$ & .694 & .058 & .569 & 11.960 & .000 \\
\hline
\end{tabular}

\begin{tabular}{|c|c|c|c|}
\hline \multicolumn{4}{|c|}{ Table 6: Descriptive Statistics } \\
\hline & Mean & Std. Deviation & $\mathrm{N}$ \\
\hline Mean Customer Value Equity & 3.5425 & .81355 & 300 \\
\hline Mean Customer Relationship Equity & 3.4485 & .72239 & 300 \\
\hline
\end{tabular}

\begin{tabular}{|c|c|c|c|c|c|c|c|c|c|}
\hline \multicolumn{10}{|c|}{ Table 7: Model Summary } \\
\cline { 5 - 9 } $\begin{array}{c}\text { Mod } \\
\text { el }\end{array}$ & $\mathrm{R}$ & $\begin{array}{c}\mathrm{R} \\
\text { Square }\end{array}$ & $\begin{array}{c}\text { Adjusted } \\
\text { R Square }\end{array}$ & $\begin{array}{c}\text { Std. Error } \\
\text { of the } \\
\text { Estimate }\end{array}$ & $\begin{array}{c}\text { R Square } \\
\text { Change }\end{array}$ & $\begin{array}{c}\text { F } \\
\text { Chang } \\
\mathrm{e}\end{array}$ & df1 & df2 & $\begin{array}{c}\text { Sig. F } \\
\text { Change }\end{array}$ \\
\hline 1 & $.628^{\mathrm{a}}$ & .395 & .393 & .63392 & .395 & $\begin{array}{c}194.45 \\
1\end{array}$ & 1 & 298 & .000 \\
\hline \multicolumn{7}{|c|}{ a. Predictors: (Constant), Mean Customer Relationship Equity } \\
\hline
\end{tabular}

The third hypothesis of the study is,

\section{H3: Customer brand equity has a significant positive effect on customer relationship equity.}

Regarding H3, the customer brand equity was also regressed with customer relationship equity. Results show in descriptive statistics that the relationship between customer brand equity and customer relationship equity seems closely related. The regression analysis as in model summary and ANOVA reveal that the model between the two factors (customer brand equity and customer relationship equity) is significant. Further, the beta coefficient value of customer brand equity reveals that customer brand equity has seventy-nine explanatory roles in influencing customer relationship equity. Hence, hypothesis $\mathrm{H} 3$ is therefore supported

\begin{tabular}{|c|c|c|c|c|c|c|c|c|c|}
\hline \multicolumn{10}{|c|}{ Table 8: ANOVA $^{\mathrm{a}}$} \\
\hline \multicolumn{2}{|c|}{ Model } & \multicolumn{2}{|c|}{ Sum of Squares } & \multirow{2}{*}{$\begin{array}{c}\mathrm{Df} \\
1 \\
\end{array}$} & \multicolumn{2}{|c|}{ Mean Square } & \multicolumn{2}{|c|}{$\mathrm{F}$} & \multirow{2}{*}{$\begin{array}{l}\text { Sig. } \\
.000^{\mathrm{b}}\end{array}$} \\
\hline \multirow[t]{3}{*}{1} & Regression & \multicolumn{2}{|c|}{78.142} & & \multicolumn{2}{|c|}{78.142} & \multicolumn{2}{|c|}{194.451} & \\
\hline & Residual & \multicolumn{2}{|c|}{119.754} & 298 & \multicolumn{2}{|c|}{.402} & & & \\
\hline & Total & \multicolumn{2}{|c|}{197.896} & \multicolumn{3}{|l|}{299} & & & \\
\hline \multicolumn{10}{|c|}{ a. Dependent Variable: Mean Customer Value Equity } \\
\hline \multicolumn{10}{|c|}{ Predictors: (Constant), Mean Customer Relationship Equity } \\
\hline \multicolumn{10}{|c|}{ Table 9: Coefficients ${ }^{\mathrm{a}}$} \\
\hline \multirow{2}{*}{\multicolumn{3}{|c|}{ Model }} & \multicolumn{3}{|c|}{ Unstandardized Coefficients } & \multirow{2}{*}{\multicolumn{2}{|c|}{$\begin{array}{c}\text { Standardized } \\
\text { Coefficients } \\
\text { Beta }\end{array}$}} & \multirow[t]{2}{*}{$\mathrm{T}$} & Sig. \\
\hline & & & \multicolumn{2}{|l|}{$\mathrm{B}$} & Std. Error & & & & \\
\hline \multirow[t]{2}{*}{1} & \multicolumn{2}{|c|}{ (Constant) } & 1.102 & & & \multicolumn{2}{|c|}{ Beta } & 6.164 & .000 \\
\hline & \multicolumn{2}{|c|}{$\begin{array}{c}\text { Mean Customer } \\
\text { Relationship Equity }\end{array}$} & .708 & \multicolumn{2}{|c|}{.051} & \multicolumn{2}{|c|}{.628} & 13.945 & .000 \\
\hline
\end{tabular}




\begin{tabular}{|c|c|c|c|}
\hline \multicolumn{4}{|c|}{ Table 10: Descriptive Statistics } \\
\hline & Mean & Std. Deviation & $\mathrm{N}$ \\
\hline Mean Customer Relationship Equity & 3.4485 & .72239 & 300 \\
\hline Mean Customer Brand Equity & 3.5795 & .66771 & 300 \\
\hline
\end{tabular}

\begin{tabular}{|c|c|c|c|c|c|c|c|c|c|}
\hline \multicolumn{10}{|c|}{ Table 11: Model Summary } \\
\hline \multirow{2}{*}{$\begin{array}{c}\text { Mod } \\
\text { el }\end{array}$} & \multirow[t]{2}{*}{$\mathrm{R}$} & \multirow{2}{*}{$\begin{array}{c}\mathrm{R} \\
\text { Square }\end{array}$} & \multirow{2}{*}{$\begin{array}{l}\text { Adjusted } \\
\text { R Square }\end{array}$} & \multirow{2}{*}{$\begin{array}{l}\text { Std. Error } \\
\text { of the } \\
\text { Estimate }\end{array}$} & \multicolumn{5}{|c|}{ Change Statistics } \\
\hline & & & & & $\begin{array}{l}\text { R Square } \\
\text { Change }\end{array}$ & $\begin{array}{c}\mathrm{F} \\
\text { Chang } \\
\mathrm{e}\end{array}$ & df1 & $\mathrm{df} 2$ & $\begin{array}{c}\text { Sig. F } \\
\text { Change }\end{array}$ \\
\hline 1 & $.785^{\mathrm{a}}$ & .616 & .615 & .44832 & .616 & $\begin{array}{c}478.32 \\
2\end{array}$ & 1 & 298 & .000 \\
\hline
\end{tabular}

\begin{tabular}{|c|c|c|c|c|c|c|c|c|}
\hline \multicolumn{9}{|c|}{ Table 12: ANOVA $^{\text {a }}$} \\
\hline \multicolumn{2}{|c|}{ Model } & \multicolumn{2}{|c|}{ Sum of Squares } & Df & \multicolumn{2}{|c|}{ Mean Square } & \multirow{2}{*}{$\begin{array}{l}\mathrm{F} \\
478.322\end{array}$} & \multirow{2}{*}{$\begin{array}{l}\text { Sig. } \\
.000^{\mathrm{b}}\end{array}$} \\
\hline \multirow[t]{3}{*}{1} & Regression & \multicolumn{2}{|c|}{96.137} & 1 & \multicolumn{2}{|c|}{96.137} & & \\
\hline & Residual & \multicolumn{2}{|c|}{59.895} & 298 & & & \\
\hline & Total & \multicolumn{2}{|c|}{156.032} & 299 & \multicolumn{2}{|c|}{.201} & & \\
\hline \multicolumn{9}{|c|}{ a. Dependent Variable: Mean Customer Relationship Equity } \\
\hline \multicolumn{9}{|c|}{ b. Predictors: (Constant), Mean Customer Brand Equity } \\
\hline \multicolumn{9}{|c|}{ Table 13: Coefficients ${ }^{\mathrm{a}}$} \\
\hline \multirow{2}{*}{\multicolumn{3}{|c|}{ Model }} & \multicolumn{3}{|c|}{ Unstandardized Coefficients } & $\begin{array}{l}\text { Standardized } \\
\text { Coefficients }\end{array}$ & \multirow[t]{2}{*}{$\mathrm{t}$} & \multirow[t]{2}{*}{ Sig. } \\
\hline & & & $\mathrm{B}$ & \multicolumn{2}{|l|}{ Std. Error } & Beta & & \\
\hline \multirow[t]{2}{*}{1} & \multicolumn{2}{|l|}{ (Constant) } & .409 & .141 & & & 2.891 & .004 \\
\hline & $\begin{array}{l}\text { Mean Customer } \\
\text { Equity }\end{array}$ & Brand & .849 & .039 & & .785 & 21.871 & .000 \\
\hline
\end{tabular}

\section{DISCUSSION}

The basic aim of the study to investigate the linkage among customer equity drivers and to build the customer value equity model. The result of hypotheses testing showed that customer brand equity and customer relationship equity has significant effect on customer value equity. Customer value equity plays a very important role for creating a customer equity for any company but customer value equity is influenced by the both customer brand equity and customer relationship equity, hypotheses testing showed that the beta coefficient of customer brand equity (.569) has fifty-seven explanatory roles in influencing customer value equity (see table 5) and similarly the beta coefficient of customer relationship equity (.628) has sixty-three explanatory roles in influencing customer value equity (see table 9). Customer brand equity also influence the customer relationship equity the coefficient beta of customer brand equity (.785) has seventy-nine explanatory roles in influencing customer relationship equity (see table 13).

Finally, the findings of the study suggest that to create customer value equity, customer brand equity and customer relationship equity plays a very important role and both the drivers of customer equity that is customer brand equity and customer relationship equity ultimately create the value for the company which, leads to create customer value equity. We can also say that from the test result of the hypothesis is that "Customer Value Equity Model" can be a very important tool for any company or by using "Customer Equity Model" any company of the world can easily create the value for the customer. Customer equity is the order of the world nowadays and every customer is looking for the value. As we can say customer value equity is the customer analysis the amount of money they give for the benefit they receive from the brands (Rust et al., 2004; Hogan, Lemon \& Zeithml, 2001; Aaker \& 
Jacobson, 1994). Therefore, every company should focus on creating the customer equity for the success of the company.

\section{CONCLUSION}

This study examines the relationship among customer equity drivers and develops the customer value equity model. Many companies are facing the problem of how to use the customer equity and which driver should be focused first and which driver should be focused second and which one third. By exploiting the relationship among customer equity drivers, a customer value equity model was developed and tested in the fast food sector. Data was collected from three hundred consumers of fast food restaurants. The findings of the study revealed that there is a significant relationship among the customer equity drivers such that brand equity of a fast food restaurant is significantly related with customer value equity as well as customer relationship equity. Similarly, customer relationship equity is significantly related with customer value equity.

There is a significant relation among the drivers of the customer equity and both the drivers i.e. customer brand equity and customer relationship equity ultimately strengthen the customer value equity, which leads to create the customer equity for the company or we can say that "Customer Value Equity Model". While critically reviewing the customer equity literature, this study believes that different topologies of customer equities lead towards the same outcome. More simply, whether it is the customer based brand equity model of Keller (Baldauf, Cravens \& Binder, 2003), the five components model of Aaker (Zeithaml, Bitner \& Gremler, 2006) which includes brand awareness, brand loyalty, perceived quality, and brand associations. Similarly, customer equity also covers relationship equity and value equity. Relationship equity covers customer equity from the perspective of customer and brand relationship whereas value equity covers the customer's objective assessment of the utility of a brand based on his or her perception of benefits to cost (Rust et al., 2001). The outcome of these three drivers is same such that the eventual outcome of relationship equity in the customer equity topology is the consumer bonding with the brand. Similarly, consumer loyalty is the ultimate outcome of consumer brand equity in the customer equity topology. The study findings present important theoretical and practical implications along with future research directions

\section{LIMITATIONS AND FUTURE RESEARCH DIRECTIONS}

Like all other researchers this research has also some limitations. Previous studies are focused on sales, repurchase intention and customer satisfaction by using customer equity (Goodchild \& Callow, 2001). The model proposed contains the linkage between customer based brand equity, customer relationship equity and customer value equity. Hence, the very first limitation of this study is that it can further validate the model by linking with other variables that can reflect the market outcomes such as brand marketing and financial performance, customer satisfaction etc. The second limitation is that the model was tested in fast food industry. It could be further tested in various other sectors so that its validity should be further strengthened.

In future each of the customer equity drivers could be further explored for its respective antecedents. By using this "Value Equity Model" other models can also create like "Brand Equity Model" and "Relationship Equity Model" which can be very useful addition to the existing models of customer equity.

\section{REFERENCES}

Aaker, D. A. \& Jacobson, R. (1994), "Study Shows Brand-Building Pays Off for Stockholders, Advertising Age, 65 (30).

Aaker, D. A. \& Jacobson, R. (2001), “The Value Relevance of Brand Attitude in High-Technology 
Markets", Journal of Marketing Research, 38(4), 485-494.

Aaker, D. A. (1991), "Managing Brand Equity: Capitalizing on the Value of a Brand Name”, New York: The Free Press, 24.

Aaker, D. A. (1996b), "Building Strong Brands",New York: Free Press.

Aaker, D. A. (1998), "Marcas-Brand Equity-Gerenciando o valor da marca”, São Paulo: Elsevier.

Aaker, D. A. (2002), "Brand Leadership", London: Simon \& Schuster.

Agarwal, M. K. \& Rao, V.R. (1996), "An empirical comparison of Consumer-Based Measures of Brand Equity”, Marketing Letters, 7(3), 237-247.

Anderson, J. C. \& Narus, J.A. (1984), “A Model of the Distributor's Perspective of DistributorManufacturer Working Relationships" Journal of Marketing, 48, 62-74.

Baldauf, A., Cravens, K. S. \& Binder, G. (2003), "Performance consequences of brand equity management: evidence from organizations in the value chain", Journal of Product and Brand Management, 12 (4), 220-236.

Bendixen, M., Bukasa, K. A. \&. Abratt, R. (2004), "Brand Equity in the Business-to-Business Market, Industrial Marketing Management, 33, 371-380.

Berger, D. Paul., N. B. Ruth., Bowman, B.D. Briggs, V. Kumar, A. Parasuraman, \& Terry, C. (2002), "Marketing Assets and the Value of Customer Assets: A Framework for Customer Asset Management." Journal of Service Research,5(1), 39-54.

Berry, L. \& Leonard, L. (1995), "Relationship Marketing of Services-Growing Interest, Emerging Perspectives", The Academy of Marketing Science, 23 (4), 236-245.

Blattberg, R. C. \& Deighton, J. (1996), "Manage Marketing by the Customer Equity Test", Harvard Business Review, 74(4), 44-136.

Blattberg, R. C., Getz, G. \& Thomas, J. S. (2001), "Customer Equity: Building and Managing Relationships as Valued Assets", Boston, Massachusetts: Harvard Business School Press.

Buttle, F. (1996), "SERVQUAL: Review, Critique, Research Agenda", European Journal of Marketing, 30(1), 8-32.

Capferer, J. N. (2006), "Strategic Management for the Brand, Translated by Sina Ghorbanlou", Tehran: Moballeqan.

Christodoulides, G. \& Chernatony, L.G. (2009), "Consumer-Based Brand Equity Conceptualisation and Measurement: A Literature Review", International Journal of Market Research, 52 (1), 43-66.

Cobb-Walgren, C. J., Ruble, C.A. \& Donthu, N. (1995), "Brand Equity, Brand Preference, and Purchase Intention", Journal of Advertising, 24 (3), 25-40.

Crawford, M. \& Benedetto, A. (2006), "New Products Management", ed. $8^{\text {th }}$, New York: McGrawHill.

Crescitelli, E.\&Figueiredo, J. B. (2009), "Brand Equity Evolution: A System Dynamics Model”, BAR Curitiba, 6(2), 101-117.

Duncan, T. \&Moriarty, S. (1997) "Driving Brand Value: Using Integrated Marketing to Manage Profitable Stakeholder Relationships", New York: McGraw-Hill, 16.

Goodchild, J. \& Callow, C. (2001), “Brands: Visions \& Values”, New York: John wiley\& Sons.

Hogan, J. E., Lemon, K. N. \& Rust, R. T (2002), "Customer Equity Management: Charting New Directions for the Future of Marketing", Journal of Service Research, 5(1), 4-12.

Javanmard, H. \& Soltanzadeh, A. (2009), "Examining the Characteristics of Internet and Websites Brand, and Their Effect on Customers' Trust and Loyalty (case study: purchasing cultural products through internet)", Quarterly Journal of Commerce, 53.

Johnson, B. \& Nunes. (2003), "Let's Talk: Applying the Art of Conversation to Customer Contact, in J.G. Freeland (Ed.), The Ultimate CRMHandbook", New York: McGraw-Hill.

Kapferer, J. (2004), “OQue VaiMudar as Marcas", Porto Alegre: Bookman.

Kazemi, A., Abadi, H. R. D., \& Kabiry, N. (2013), "Analyzing the Effect of Customer Equity on Repurchase Intention", International Journal of Academic Research in Business and Social Sciences, $3(6), 78-89$.

Keller, K. L. (1998), "Branding Perspectives on Social Marketing”, Advances in Consumer Research, 


$$
\text { 25, 299-302. }
$$

Keller, K. L. (2003), "Strategic Brand Management: Building: Measuring, and Managing Brand Equity", ed.2 ${ }^{\text {nd }}$, New Jersey: Prentice Hall.

Kristof, D. W., Odekerken-Schröder, G. \& Iacobucci, D. (2001), "Investments in Consumer Relationships: A Cross-Country and Cross-Industry Exploration", Journal of Marketing, 65 (4), 33-50.

Kumar, V. \& George, M. (2007) "Measuring and Maximizing Customer Equity: A Critical Analysis" http://www.12thinktank.com/luxury2010digitaliq/luxury2010digitaliq.pdfLavidge, R. J. \& Steiner, G. A. (1961), “A Model for Predictive Measurements of Advertising Effectiveness", Journal of Marketing, 25(6), 59.

Leone, R., Rao, \& Keller, K. (2006), "Linking Brand Equity to Customer Equity”, Journal of Service Research, 9(2), 125-138.

Lewin, J. E. \& Johnston, W. J. (1997), "Relationship Marketing Theory in Practice: A Case Study", Journal of Business Research, 39, 23 - 31 .

Liu, B. S., Sudharshan, D. \& Hamer, L.O. (2000), "After Service Response in Service Quality Assessment: A Real Time Up Dating Model Approach”, Journal of Service Marketing”, 14 (2), 160-177.

Mittal, B \& Kamakura, W. A. (2001), "Satisfaction, Repurchase Intention, and Repurchase Behavior: Investigating the Moderating Effect of Customer Characteristics", Journal of Marketing Research, XXXVIII (1), 131-142.

Mizik, N. \& Jacobson, R. (2009), "Valuing Branded Businesses”, Journal of Marketing, 73 (6), 137 153.

Nykamp, M. (2001), “The Customer Differential: The Complete Guide to Implementing Customer Relationship Management", New York: AMACOM.

Payne, A. \& Frow, P. (2005), “A strategic framework for customer relationship management”, Journal of Marketing, 69(4), 167-76.

Peppers, D. \& Rogers, M. (1993), “The One to One Future, Double Day, Division of Bantam Double Day". New York: Dell Publishing Group.

Raggio, R. D \& Leone, R. P. (2007), "The Theoretical Separation of Brand Equity and Brand Value: Managerial Implications for Strategic Planning”, Journal of Brand Management, 14 (5), 380-395.

Richards, K. A. \& Jones, E. (2008), "Customer Relationship Management: Finding Value Drivers", Industrial Marketing Management, 37(2), 30-120.

Rust, R. T. \& Verhoef, P. C. (2005), "Optimizing the Marketing Interventions Mix in IntermediateTerm CRM", Marketing Science, 24 (3), 24-489.

Rust, R. T., Lemon, R. K \& Zeithaml, V. A. (2001), "Driving Customer Equity: Linking Customer Lifetime Value to Strategic Marketing Decisions", Marketing Science Institute, Cambridge, MSI, 1-53.

Rust, R. T., Lemon, R. K \& Zeithaml, V. A. (2004), "Return on Marketing: Using Customer Equity to Focus Marketing Strategy", Journal of Marketing, 68, 109-127.

Rust, R. T., Lemon, R. K. \& Zeithaml, V. A. (2006), "Measuring Customer Equity and Calculating Marketing ROI" in R. Grover, M. Vriens, "The Handbook of Marketing Research: Uses, Misuses and Future Advances", SAGE Publications, 588-601.

Sekaran, U. (2003), “Research Methods for Business" ed. $4^{\text {th }}$, New York: John Wiley \& Sons Inc.

Selnes, F. (1998), "Antecedents and Consequences of Trust and Satisfaction in Buyer-Seller Relationships", European Journal of Marketing, 32, 305-322.

Slotegraaf, R. J \& Pauwels, R. (2006), “Growing Small Brands: Does a Brand's Equity and Growth Potential Affects its Long-Term Productivity? MSI Reports, Working Paper Series, 4 (06004), 6-23.

Stahl, F. \& Heitmann, M. (2012), "The Impact of Brand Equity on customer Acquisition, Retention, and Profit Margin", Journal of Marketing, 76, 44-63. 
Taylor, S. A., Celuch, K. \& Goodwin, S. (2004), "The Importance of Brand Equity to Customer Loyalty", Journal of Product \& Brand Management.

Vogel, V., Evanschitzky, H. \& Ramaseshan, B. (2008), "Customer-Equity Drivers and Future Sales", Journal of Marketing, 72 (6), 98-108.

Wood, L. (2000), "Brands and Brand Equity: Definition and Management", Management Decision, $38(9), 662-669$.

Wu, T. F. \& Batmunkh, M. U. (2010), "Exploring the Relationship between Customer Equity and Satisfaction: An Empirical Study of Mongolian Gas Station Channels", International Journal of Trade, Economics and Finance, 1(2), 160-166.

Zeithaml, V.A. (1988), "Consumer Perceptions of Price, Quality, and Value: A Means-End Model and Synthesis of Evidence", Journal of Marketing, 52 (3), 2-22.

Zeithaml, V. A., Bitner, M.J. \& Gremler, D.D. (2006), "Services Marketing: Integrating Customer Focus Across the Firm", ed. $4^{\text {th }}$, New York: McGraw-Hill. 